\title{
Feminist Aktivizmin Temsil Alanı Olarak Sanat: Guerrilla Girls
}

\section{Art as the Representation Field of Feminist Activism: Guerrilla Girls}

Deniz Reka, Radyo, Televizyon ve Sinema Bölümü, İstanbul Yeni Yüzyıl Üniversitesi

\begin{abstract}
Özet
Sanat alanındaki üretim süreçlerinden, piyasanın işleyiş dinamiklerine, sanatçının yaratım süreçlerinden kazandığı kimliğin etkisine bütünsel bir yaklaşım olarak ele alındığında feminist teori; dönemin siyasi aktivizminden de etkilenerek sanatı bir protesto aracı olarak kullanmıştır. Feminist aktivizmin önemli bir temsilcisi olarak sanatçı grubu Guerrilla Girls, 1980'lerin ortalarından beri cinsiyet ve Irk eşitsizliğini üretimlerinin temel noktası haline getirdikleri çalışmaları ve mizahi eylem biçimleriyle feminist bir karşı kültür oluşturmuştur. $\mathrm{Bu}$ bağlamda çalışma, sanat dünyasındaki cinsiyet eşitsizliğine dikkat çeken bağımsız feminist sanatçı grubu Guerrilla Girls'ün eserlerini, feminist aktivizmin sanat alanındaki temsili bağlamında ortaya koyma amacı taşımaktadır. Sanat piyasasının dışlayıcı tutumları nedeniyle galeri mekanlarında kendine yer bulamayan sanatçıların afiş, poster, billboard, etiket ve çıkartmalarla kamusal alanda sergiledikleri eserler, aktivizmle ilişkisi çerçevesinde yorumlanmıştır. Literatürde kadının sanatçı kimliğiyle sanat dünyası içerisindeki konumunu ele alan çalışmaların sayısı az olduğundan çalışmanın sanat iktidarını aşmada ve cinsiyet eșitsizliğine getirilen eleştirinin özgürce ortaya konabilmesinde zorunlu olarak kullanılan kamusal alana dikkat çekmesi nedeniyle önem taşıdığı düşünülmektedir. Panofsky'nin ikonografik ve ikonolojik çözümleme yöntemi ile incelenen beș çalıșmanın doğal, uzlașımsal ve içeriksel anlamları eril bakışın kadınlara atfettiği unsurlar ve grubun mizahi söylemleri bağlamında incelenmiştir.
\end{abstract}

Anahtar Sözcükler: Feminist sanat, aktivizm, kamusal alan, Guerrilla Girls.

Akademik disipin(ler)/alan(lar): Sanat tarihi, grafik.

\begin{abstract}
Feminist theory is considered as a holistic approach to the production processes in the field of art, to the dynamics of the functioning of the market, to the effect of the identity the artist gains from the creative processes; influenced by the political activism of the period, he used art as a means of protest. As an important representative of feminist activism, the artist group Guerrilla Girls has created a feminist counterculture since the mid-1980s with their work and humorous forms of action that have made gender and racial inequality the main point of their production. The study aims to reveal the works of Guerrilla Girls, an independent feminist artist group that draws attention to gender inequality in the art world, in the context of the representation of feminist activism in the field of art. The works such as posters, billboards, labels and stickers exhibited by the artists who cannot find a place in the gallery spaces due to the exclusionary attitude of the art market have been interpreted within the framework of their relationship with activism. In the literature, the number of studies dealing with the artist identity of women and their position in the art world is very few. In addition, it is thought that the study is important because it draws attention to the public sphere used in overcoming the power of art and expressing the criticism against gender inequality freely. The natural, conventional, and intrinsic meanings of five work which were examined with Panofsky's iconographic and iconological analysis method, were examined in the context of the elements attributed to women by the masculine view and the humorous discourse of the group.
\end{abstract}

Keywords: Feminist art, activism, public sphere, Guerrilla Girls.

Academical disciplines/fields: History of art, graphic.

- $\quad$ Sorumlu Yazar: Deniz Reka, Radyo, Televizyon ve Sinema Bölümü, İstanbul Yeni Yüzyıl Üniversitesi

- Adres: Maltepe Mahallesi, Yılanlı Ayazma Caddesi, No: 26 P.K. 34010 Cevizlibağ, Zeytinburnu / İstanbul

- $\quad$ e-posta: deniz.reka@yeniyuzyil.edu.tr

- ORCID: 0000-0003-1678-6362

- Cevrimiçi yayın tarihi: 22.06 .2021

- doi: $10.17484 /$ yedi. 900063 


\section{Giriş}

Cinsiyetler arası eșitliği ve toplumda kadının konumunu güçlendirmeye yönelik fikirlerin özünü oluşturduğu feminizm, bir teori olmanın yanında hukuksal, cinsiyetler arası ve toplumsal ilişkilerde politik bir tavrı da içerir. Sosyolog Andrée Michel "kadınların toplum içindeki rolünü ve haklarını genişletmeyi öngören bir doktrin” olarak feminizm sözcüğünün Fransızcaya 1837'den sonra girdiğini belirtir (Saygılıgil ve Berber, 2020, s. 15). Sözcük, günümüzde mücadele fikrini kapsayarak kabul gören anlamıyla ilk olarak Fransız süfrajist Hubertine Auclert (1848-1914) tarafından kullanılmıştır. Feminizm, kadınların erkeğin yanındaki ikincil konumlarını, cinsiyet normlarını, hiyerarşik bir düzene göre oluşturulmuş eril ve dişil tanımlarını hedef alan; kadınların hakları, düşünce ve hareket özgürlükleri adına girișilen bir mücadeledir (Rochefort, 2020, s. 7). Tek bir feminizm terimi yerine 'feminizmler' teriminin kullanımının daha doğru olduğunu belirten Rochefort (2020), bunu tarihsel perspektiften bakıldığında gerçekleştirilen mücadelelerin çeșitliliği ile ilișkilendirmiștir. Feminizm kendini çelișkili, tartıșmalı olguları kapsayan felsefi ve politik düşünce akımları kadar toplumsal ve siyasi hareketler aracılığıyla da göstermiştir. İçinde bulunulan tarihsel dönemin koşullarına, karşı koyduğu baskı biçimine, eşitlik ve özgürlük kavramlarına yüklenen anlamların göreceliğine bağlı olarak değişkenlik gösteren kadın hareketleri, çoğul ekinin kullanımını gerekli kılan karmașık bir harita meydana getirmiștir.

Tarihsel dönemlendirmeler içerisinde ilki olan 'birinci dalga feminizm' 1890'lı yıllardan 1960'lı yıllara kadarki dönemde kadınların oy kullanma, eğitim ve çalışma hakları gibi temel mücadele alanlarını kapsamaktadır. 1968 sonrası ve ikinci dalga olarak adlandırılan dönemde ise yasalarla sağlanmıș eșit koșullara karşın kadınların erkeğe tabi olduğu ve ikincilleștirildiği ataerkil sisteme karşı bir bașkaldırı gelişir. Tekeli'ye göre (1998) ikinci dalga feminizm, kadınların bedeni, emeği ve cinselliğinin erkek egemenliği tarafından kullanılmasını eleştirerek cinsiyet rollerini sorgulamıştır. Erkek egemenliği tarafından oluşturulan yönetim ve eğitim sistemleri, medya araçları, aile gibi sürdürülen tüm kurumları sorgulamış ve onlara başkaldırmıştır. Bu dönemde kadınların uymaları beklenen toplumsal normların biyolojik cinsiyetlerinin değil söz konusu ataerkil sistemin ürünü olduğundan hareketle Simone de Beauvoir'ın "Kadın doğulmaz, kadın olunur” sözü sloganlaşır. Beauvoir, 1949'da kaleme aldığı, feminist kuramın en temel metinlerinden biri olan Íkinci Cinsiyet kitabında bu sözü; ataerkil kalıpların tarihi şekillendiren bir düşünce sistemi, kadınlığın ise bu sistem karşısında yer alan bir toplumsal durum olduğunun ifadesi olarak kullanır. Böylece 1970'lerden itibaren geliștirilen olan feminist çalıșmaların ana kavramlarından biri haline gelmiş biyolojik cinsiyet/toplumsal cinsiyet ikiliğini ortaya atmıştır (Öztürk, 2009, s. 5).

Kate Millett, Cinsel Politika (1970) eserinde patriyarkanın siyasi bir kurum olarak cinsel ilişkilere ve cinsiyet kategorisinin yüklendiği anlamlara nasıl etki ettiğini gözler önüne sermiștir. Batı’da, kadın cinselliğinin doğurganlıktan bağımsızlaștırılması bakımından önemi nedeniyle doğum kontrol yöntemlerinin yaygınlaştırılmasına dikkat çekilmiş ve erkekle ilişkisi üzerinden tanımlandığından özne haline gelemeyen kadının radikal bir öteki olarak konumlandırılması eleştirilmiştir (Öztürk, 2009, s. 6). Ataerkinin güç ilişkilerinde kadının edilgen konumlanışını eleştiren Carol Hanish'in "Kişisel olan politiktir" sözü; özel alan, kadın bedeni ve cinsellik gibi konuları siyasi erk ve toplumsal yapıyla bütünleştirerek politik sorunlar olarak ele alır. Aksu Bora'ya göre de bütün farklı kadınlık durumları, sadece cinsiyetle ilgili olmayan farklı ezilme biçimleri arasındaki bağlantıları politik bir mücadele alanına kavuşturmada feminist hareketin önemi ve feminist hareketin teorik arka planı öne çıkmaktadır (aktaran Karakaşoğlu, 2017, s. 4).

\%99 İçin Feminizm: Bir Manifesto'da (2019) firsat eșitliği vaazının peşinde koşmaya devam etmek yerine toplumsal cinsiyet eșitliğini antikapitalist bir tarzda yeniden tasavvur etme önerisinde bulunan Cinzia Arruzza, Tithi Bhattacharya'nın yanı sıra Nancy Fraser de feminizmi politik bir mücadele alanı olarak görmektedir. Fraser’a göre (2009) özel alanı kapsayan cinsellik, ev içi emek ve kadına şiddet konularıyla birlikte ikinci dalga; kadın-erkek eşitliği temelindeki adalet kavramının anlamını genişletmiş böylece cinsiyetler arası adaletsizliğin içine hiyerarşik rollerin yarattığı eşitsizliği eklemiştir. Bu dönem; ev içinde ve çocuk bakımında ücretsiz, iş yaşamında ücretli cinsiyet ayrımcı iş bölümü ile kadının üstlendiği sorumluluğu değersizleştiren toplumsal cinsiyet eşitsizliklerine karşı eleştirel bir tavır getirir. Aynı zamanda daha bütüncül bir mücadele alanı olarak feminizmin zorunlu olarak bağlantılı olduğu irkçılık, emperyalizm, homofobi ve sınıfsal tahakküm kavramları da ele alınmıștır. 
ABD'de 'ikinci dalga' olarak anılan döneme yeni neslin kendini kadın hakları hareketinden soyutlamasından hareketle daha çok 'sıfır yılı' denilen Fransa'da Christine Delphy, kurum ve ideolojilere daha siyasal araçlarla meydan okuyan feminist bir düşüncenin temsilcisi olmuştur. Marksizmden ilham alan Delpy ve Hartmann gibi materyalist feministler, özellikle kadınların ücretsiz ev içi emekleriyle sömürülmesini kuramsallaștırmıștır (Rochefort, 2020, s. 24-25). Hartmann, ataerkinin dayandığı maddi temelin, kadınların emek gücü üzerindeki erkek denetiminde yatmakta olduğunu söyleyerek kadınların, emek piyasasındaki rolünden kazanç sağlayanın yalnızca kapitalistler değil evde kişisel hizmet alan kocalar ve babalar da olduğunu belirtir (Donovan, 2014, s. 161). Andrée Michel ise 1970’lere gelindiğinde feminizm tanımının artık yalnızca öğretiyi değil eylemi de içermek zorunda olduğunu vurgulayarak feminizmin kadınlar tarafından hep yeniden kurulan, deneyim aktarılan bir tecrübe alanı olduğunu belirtmiştir. Benzer şekilde feminist teorinin keşfetmeye açık, devrimci bir özellik taşıdığını; İkinci Dalga feministler kuşağından ve Fransızca konuşulan ülkelerde çıkan ilk feminist dergi Cahier du Grif'in kurucularından Collin (1928-2012) de şöyle ifade etmiştir:

Marx’ın Marksizm içindeki rolünü Simone de Beauvoir feminizmde oynamaz. İkinci Cinsiyeti tekrar tekrar okuyabilir, ondan esinlenebilir ve onun hakkında tartışabiliriz ama o bizim dogmamız değildir. Tarihsel olarak başvurulan bir metindir o. Ve böyle birçok metin vardır ama hiçbiri kurucu bir metin değildir. Kitap bir anlamda yazılmayı beklemektedir. (Saygllıil ve Berber, 2020, s. 16)

1970 ve 80'lerde ABD'nin çehresini değiștiren feminist hareket, yurttaşlık hakları devriminin hemen sonrasında hayat bulmuştur. Feminist aktivistlerde, tüm kadınların mutluluğu ve refahı için 'kız kardeşlik' biçiminde ifade bulan politik dayanışma ile ataerkil adaletsizliğin bütün biçimleriyle mücadele sorumluluğunun paylaşılması fikri güçlenmiştir. Feminist 'kız kardeşliğin' kökleri, ırk ve sınıfın çizdiği sınırların ötesinde cinsiyetçiliği zayıflatmak ve ataerkinin tahakkümünü ortadan kaldırmaya dayanır (Hooks, 2012, s. 29). Sanat piyasasının kadınlara yönelik ayrımcı tutumlarını eleștiren eserleriyle tanınan Guerrilla Girls ise ırkçılık karşıtı kapsayıcı kız kardeşlik fikrinin temellendirdiği bu söylemle farklı ezilme biçimleri arasındaki bağlantıları sanat alanına taşımışlardır. 1985 yılında aktif olarak eserler üretmeye başlayan Guerrilla Girls, daha çok ikinci dalga feminist kuşağı içerisinde değerlendirilen; sanat piyasasında kadına yönelik ikincil ve dışlayıcı tutumu konu alan afiş, billboard, etiket ve çıkartmalar üreten, ABD'li aktivist ve sanatçı grubudur. İlk yaptıkları afişlemeden sonra basında çıkan haberlerde yapılan kelime hatası nedeniyle grubun ismi 'Gorilla Girls' olarak yer almıștır. Bu isimlendirmeyi benimseyerek mizahi bir tercihle goril maskeleri kullanmaya başlayan sanatçı inisiyatifi (bkz. Şekil 1) anonim olma tercihinin öznelerinden bağımsızlaşarak sorunlara odaklanmayı sağladığı düşüncesiyle kimliklerini gizli tutmaktadır.

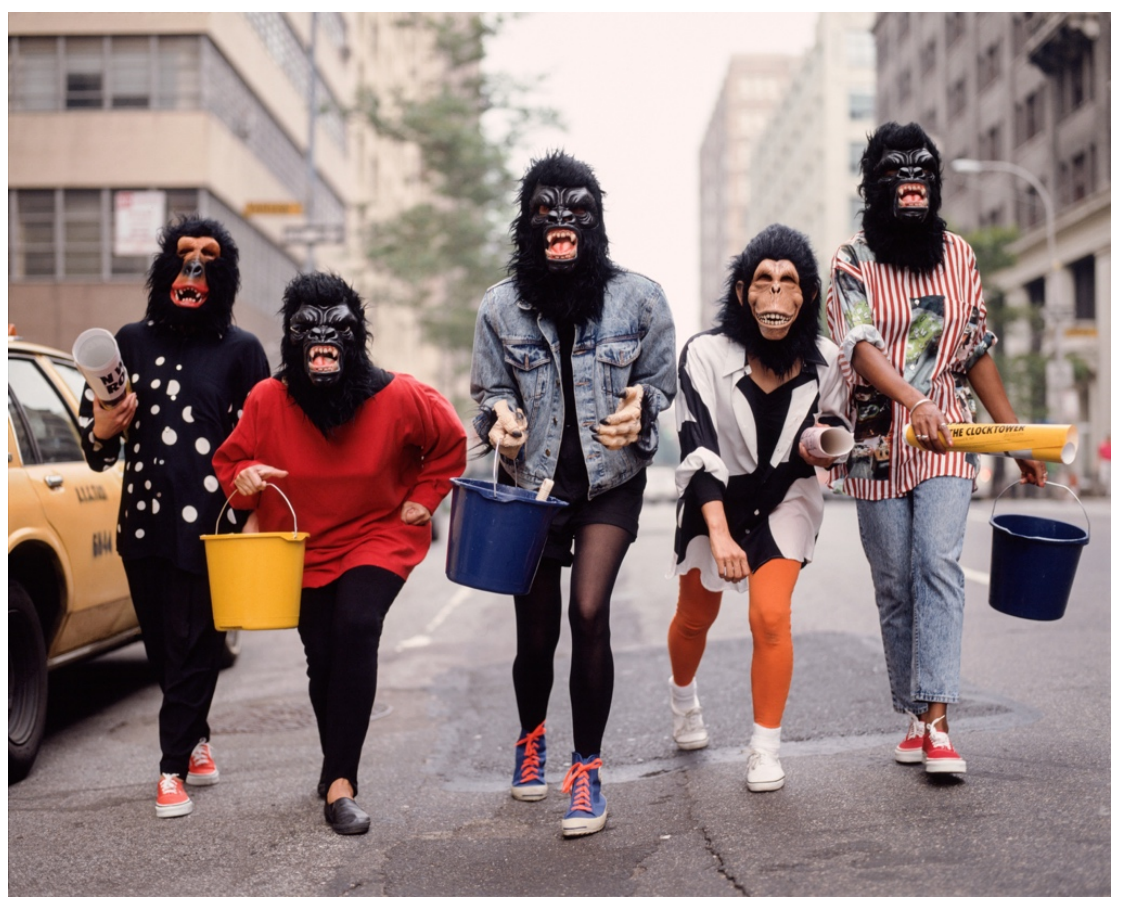

Şekil 1. Guerrilla Girls (Guerrilla Girls_Artist, t.y.). 
Aynı doğrultuda sanat tarihinden seçtikleri kadın sanatçlların isimlerini (Alma Thomas, Hannah Höch, Frida Kahlo, Kathe Kollwitz, Alice Neel, Julia de Burgos vb.) kullanan bağımsız topluluk, başlangıçta çoğunlukla sergi mekanlarının dışında ve kamusal alanda aktivist eylemler gerçekleştirmiştir. New York, Minneapolis, Los Angeles, Londra, Mexico City, İstanbul, Bilbao ve Şanghay da dahil olmak üzere dünyanın dört bir yanında 100'den fazla sokak projesi ile müzelerin dış cephelerine yaptıkları müdahaleler ve projeksiyonlar vasıtasıyla kamusal alan projeleri gerçekleștirmiștir (Guerrilla Girls, t.y.-a). Tarihin yazılması ve aktarılması sürecinde kadının özne yerine daha çok nesne oluşuna eleştirel yaklaşan feminist teoriyi bir araç olarak kullanmakta, eylemleri/üretimleriyle sanat tarihi ve piyasasındaki cinsiyet ayrımcı kurumsal düzeni eleştirmektedirler. Eril tahakkümün diğer hiyerarşi biçimleriyle iç içe geçmiş yapısına ve kadınların yok sayılmasına karşın feminizmi, sanat alanında ideolojik bir temsil olarak ele alırlar. Bu bağlamda çalıșmanın amacı, sanat dünyasındaki cinsiyet eşitsizliğine dikkat çeken bağımsız feminist sanatçı grubu Guerrilla Girls'ün eserlerini, feminist aktivizmin sanat alanındaki temsili bağlamında ortaya koymaktır.

Kamusal ile özel, iş ile yuva, eşitlik ve farklılık gibi üzerinde çok fazla konuşulan erkekler ve kadınlar arasındaki karmaşık ve kaygan ilişkilerin kavranması, yakın zamanda gerek feminizm tarihi gerekse kamusal alandaki kadınların tarihi üzerine araștırmaları çıkmaza sokan sorunların çözümüne katkı sağlayabilir. Bu nedenle kadınların kamusal erkek dilini, söylemi bozucu tarzda kullanma yöntemlerinin, böylesi bir bozuma uğratmanın uzun vadeli sonuçlarının neler olduğunun dikkatlice incelenmesi gerekmektedir (Jordanova'dan akt. Davidoff, 2002, s. 190). Bu bakışla örtüşecek şekilde çalışmada "Guerrilla Girls sanatçı grubu, eserlerinde feminist eleştiriyi nasıl ortaya koyar?", "Kadınların henüz galeri mekanlarından dışlandığı bir dönemde kamusal alanda yapılan aktivist çalışmalar, kadın sanatçıların temsil sorunuyla nasıl bir ilişki içerisindedir?" sorularına yanıt aranmıştır. Literatürde, görsel anlatıda kadının temsili üzerine yapılan çalışmaların çokluğuna karşın sanatın erkek iktidarını aşmada ve cinsiyet eşitsizliğine getirilen eleştirinin özgürce ortaya konabilmesindeki rolü nedeniyle aktivizmi ele alan çalışmaların sayısı oldukça azdır. Kadının sanatçı kimliğiyle sanat dünyası içerisindeki konumunu ortaya koyan çalışmaların taşıdığı önemden hareketle Guerrilla Girls'ün seçilen eserleri, feminist aktivizmle ilişkisi bağlamında analiz edilmiştir.

\section{Sanatta Feminist Hareket}

Sanat tarihinin feminist bir bakışla sorgulanması 197l'de Linda Nochlin'in 'Neden Hiç Büyük Kadın Sanatçı Yok?' başlıklı makalesiyle başlar. Nochlin makalesinde, diğer alanlarda olduğu gibi sanat alanında da kadının eşitliği sorununun erkeklerin iyi veya kötü niyetinden ya da tek tek kadınların kendine güveni veya güvensizliğinden değil, kurumsal yapılarımızın niteliğinden ve bu kurumların, parçası olan insanlara dayattığı gerçeklik anlayışından kaynaklandığını belirtir. Başka yüzlerce alanda olduğu gibi engelleyici, baskıcı ve cesaret kırıcı Batılı, beyaz erkeğe özgü bakıș açısı, sanat tarihçisinin de bakış açısı olarak kabul görmüştür. Ancak bu bakış sadece manevi ve etik bakımdan değil, entelektüel bakımdan da yetersiz kalmaktadır. Çünkü 'Neden hiç büyük kadın sanatçı yok?' sorusunun ardındaki yanlış anlayıș, aynı zamanda sanatın nasıl üretildiğine ve özel olarak da büyük sanat yapıtlarının nasıl ortaya çıktığına dair birçok naif, çarpıtılmış ve sorgulanmadan kabullenilmiş düşünceyi yansitmaktadır. Bu anlayış; bireyin doğduğu günden beri gizemli bir öz taşıdığı, içinde bulunduğu koşullardan bağımsız mutlaka ortaya çıkacak bir 'deha' veya 'yetenek' sahibi olduğu, eşsiz ve tanrısal 'büyük sanatçı' mitini yansıtır. Oysa Piaget'nin genetik alanındaki araştırmalarında ortaya koyduğu gibi mantığın ve hayal gücünün gelişiminde zekâ yani buradaki bağlamda deha, sabit bir öz değil dinamik bir süreçte gelişen bir olgudur. Diğer yandan bireysel dehanın sanat yaratımında esas teşkil ettiği görüşü, özgül ve tanımlanabilir toplumsal kurumların dolayımından geçerek belirlenen sanat üretimi ve sanatçı kimliğiyle çelişmektedir (Nochlin, 1971/2014, s. 135).

Feminist sanat tarihçileri kadınlara uygun görülen rolleri açığa çıkarmak ve eleştirel olarak analiz etmek amacıyla başlangıçta kadın sanatçıların yitik tarihinin gün ışı̆̆ına çıkarılmasıyla ve imgelerin kadın bakış açısından yeniden yorumlanmasıyla ilgilenmiștir (Antmen, 2014, s. 77). Örneğin; Eleanor Tufts, 1974'te Our Hidden Heritage: Five Centuries of Women Artists, Karen Peterson ile J. J. Wilson 1976'da yayınlanan Women Artists: Recognition and Reappraisal from the Early Middle Ages to the Twentieth Century çalışmalarıyla, sanat tarihinde göz ardı edilmiş kadın sanatçıların gün yüzüne çıkarılmasını amaçlamıştır. 1970'li yılların sonlarındaki ikinci kuşak ise diğer disiplinlerdeki feminist eleştiriden etkilenmiş; sanat üretimini, sanata değer biçerken kullanılan ölçütleri ve sanatçının rolünü sorgulayarak kültüre yönelik daha karmașık bir eleştirinin doğmasını sağlamıştır (Peterson ve Mathews, 2014). Hem sistematik dışlama süreç ve yöntemleri olarak kadın sanatçının yok sayıldığı hem de ataerkil toplumsal yapının doğal bir sonucu olarak kadının, sanat üretiminin içerisinde erkek kadar yer almadığı ve böylece büyük kadın sanatçıların da ortaya çıkamadığı fikri gelişmeye başlamıştır. Kadınların sorunlarını ortaya koyma ve çözümleme çabasındaki 
feminist bakış; sanat alanındaki üretim süreçlerinden, piyasanın işleyiş dinamiklerine, sanatçının yaratım süreçlerinden kazandığı kimliğin bu sürece etkisine bütünsel bir yaklaşım olarak, dönemin siyasi aktivizminden de etkilenerek sanatı bir protesto aracı olarak kullanmaya bașlamıștır.

Feminist eleştirmenler, göstergebilim ve psikanaliz gibi disiplinlerin yardımıyla ataerkil imgelemenin sapkın güçlerini irdeleyerek, klasik anlatımcılıkta cinsiyet farklılıklarının nasıl kodlandığını çözümlemeye çalışmışlardır. İlk dönemde feminist sinema kuramı özellikle cinsellik ve sunumu ile bunun erkek iktidarının egemenliğiyle ilișkilerini ana ilgi odağı olarak benimsemiștir (Öğüt, 2009, s. 204). Kuramın öncülerinden Laura Mulvey’e göre (1997) eril bakıșın ve ataerkil toplumun bilinçdışını temsil sistemi olan sinema, politik bir silah olarak hizmet etmektedir. İkinci dalga feminist hareketin de etkisiyle 1970'li yıllardan beri özellikle sinema filmlerinin eleştirisinde kullanılmaya başlanan 'Görsel Haz ve Anlatı Sineması' makalesi, nesne veya özne konumlarının görsel yaratımının nasıl oluşturulduğunu ve neye hizmet ettiğini saptamaya çalıșmıştır. Röntgencilik yani vöyorizm ve narsistik özdeşleşme ile ilişkili olan skopofili, bakıșın hazzıdır. Bakışın hazzından doğan skopofilik halde nesneleșmiş ötekini, etkin denetleme anlamında seyreden erkeğin bakışına sunulan kadın, zevk vermek üzere teşhir edilir.

Günümüzde kabul gören büyük eserler seçkileri, H. W. Janson'ın 1962'de basılmış The History of Art'ına dayanır. Bu seçki ise ana hatlarıyla 16. yüzyıl sanatçısı ve yazar Giorgio Vasari'nin ilk kez 1550'de basılmış Büyük Ittalyan Mimar, Ressam ve Heykeltıraşların Hayatları adlı eserinden alınmıștır. Günümüzde Modern sanat tarihçileri tarafından başvurulan ve sanat tarihi yazınında hâkim olmayı sürdüren kitap, Vasari'nin öznel değer yargılarıyla geçerlilik kazandırdığı eserler yoluyla aynı zamanda eleştirmeni veya sanat tarihçisini de icat etmiştir. Vasari'nin tanımladığı sanatçı; cinsiyeti, sınıfı ve ırkı kesin olarak belirlenebilen, dolayısıyla toplumsal yaşamında özgür, üst sınıf mensubu beyaz erkektir. Feminist pratik, sanat tarihi alanındaki kanona meydan okumak, sanatçı ve eleştirmen olarak kadınlara yer açmak için bazı stratejiler geliştirmiştir. Bunlardan biri 'normal' seçkiyi eșitsiz ve sorgulanır hale getiren, böylece doğal olmaktan çlkarıp siyasi boyutunu ifşa eden kadın sanatçıların keşfidir. Böylece kanonda yer verilmiş eserlerin, estetik değerin veya anlamlı ifadenin paradigmatik örneklerinin büyük bir iktidar ilişkileri sisteminin unsurları olarak birbirlerini destekledikleri ortaya çıkmaya başlamıştır (Salomon, 2014).

Sanat alanındaki bu dışlamaya tepkilerini eylemlerinin/üretimlerinin temel noktası haline getiren Guerrilla Girls, cinsiyet ve ırk eșitsizliğini sanat camiasında odak noktası haline getirme misyonuyla posterler, afişler, reklam panoları ile halka açık yerlerde ayrımcılı̆̆ı ve yolsuzluğu ortaya çıkarmayı amaçlamıştır. 1984 yılında yedi kadın, Modern Sanat Müzesi'nin 165 sanatçının kadrosunda sadece 13 kadının yer aldığı 'Uluslararası Güncel Resim ve Heykel Araştırması' sergisini protesto etmek amacıyla MoMA'nın (Museum of Modern Art) önünde bir araya gelmiștir (Tate Kids, t.y.). Bu olayla bir araya gelen grup, ilk olarak ABD'de afiş, grafiti, karikatür, resim ve aktivist sokak eylemleri, gösteriler, sanat ve tiyatro performanslarını kullanarak mizahi eylem biçimleriyle feminist bir karşı kültür oluşturmuştur. Daha çok afişleriyle ün kazansalar da çeşitli etkinliklerde binlerce küçük el ilanı dağıtarak kadın ve erkek sanatçılar arasındaki sergi sayısı, galeri temsili ve ücret eşitsizliklerini vurgulamışlardır. Sözü edilen tüm metinler ve üretimlerde işaret edildiği gibi feminist eleştirileri, yüzyıllarca yok sayılmış kadın sanatçıları görmezden gelmek yerine yeni bir bakışla keşfetmek ve onları erkek egemen sanat tarihi disiplinine eklemlemenin yanı sıra normal sayılanı şüpheli hale getirmeyi ve kadını bakışın nesnesi olarak sunan temsile meydan okumayı amaçlamıştır (Antmen, 2014).

Rochefort'un belirttiği gibi feminizmin siyasi öznesi Batılı neoliberal hegemonyanın uluslararası protestolarla sorgulanması ve yapısallaşan ırkçılığın, yaşanan adaletsizliklerin ifşası eş zamanlı olarak gerçekleşmiştir. Böylece yeni tarihsel çalışmalar yürütülmesi ve kendini her alanda dayatabilecek bir eril tahakküm fikri karşısında; cinsiyet, sınıf ve ırk ilişkilerinin kesişimselliğini; etnik, ulusal, dini, kuşaklar arası çeşitli aidiyetleri incelemeye yönelik öneriler ortaya çıkmıştır. Guerilla Girls gibi çağdaş feminizmlerin yeni sözcüleri; birçok ulusu ilgilendiren bu sorunsalların kökenine, azınlıkların ifadelerine farklı sosyal ve siyasi hareketlerle kurulan etkileşime önem vermiştir (Rochefort, 2020, s. 11). Bu doğrultuda, odak noktaları küratörlerin, sanat tacirlerinin, koleksiyoncuların ve eleştirmenlerin cinsiyetçi politikalarına ilişkin diyaloğu geliştirmek ve sanatta cinsiyetçiliğe dikkat çekmek olsa da kısa süre sonra çalışmalarının odaklarını genişletmişlerdir. Siyahi sanatçıların sanat dünyasındaki ırkçılığa maruz kalmasını konu alan New York dışı projeler gerçekleştirmiş, ayrıca ulusal ve uluslararası düzeyde gündemde yer alan filmlere, popüler kültür ürünlerine ve siyasete yönelik cinsiyetçilik ve ırkçılık eleştirilerini de konu almaya başlamışlardır. 


\subsection{Kamusal Alanda Sanat}

'Kamusal alan' kavramıla kendi içinde bir anlamda kamuoyuna benzer bir alanın oluşturabileceği, toplumsal yaşamımızın bir parçasını tanımlıyoruz. Kamusal alanın en önemli niteliği tüm vatandaşlara açı olmasıdır. Kamusal alanın bir bölümü, özel vatandaşların birbirleriyle bir kamu organı yarattıkları her türlü iletişim sayesinde yaratılır. Vatandaş olarak tanımladığımız bireylerin ancak ve ancak toplumsal çevrelerinde herhangi bir sınırlama olmaksızın -diğer bir deyişle, kendi düşüncelerini özgürce açılklayıp yayımlama hakkı ve özerk grup örgütlenmeleri kurma hakkının garantisi altında- hemen herkesi ilgilendiren sorunlar hakkında birbirleriyle etkileşimde bulunabildiklerinde bir kamusal alan olarak davranabilmeleri olasıdır (Habermas, 1995). Habermas'ın tasvir ettiği özgürce ifade olanağı tanıyan ve sosyal etkileşime imkân veren alanlardan kentsel mekânda sanat, mekân ve izleyicisiyle doğrudan diyalog kurabilmekte, sanatçı ise konu edindiği sorunlar hakkında özgürce etkileşimde bulunabilmektedir. Bu bakımdan kamusal alanda sunulan sanat, interaktif bir süreçte nesnesi tarafından anlamlandırılırken sınırlama olmaksızın geniş kitlelerle buluşabilmektedir. Böylece kent mekânı olarak sokak; bir müze, küratör veya galerinin dolayımı olmaksızın sanatçı ile izleyici arasındaki tüm kurumları, kişileri ortadan kaldırarak sanatın politik duruşuna ve aktivizme de imkân vermektedir.

Kamusal alanda sanat fikri, 1. Dünya Savaşı sonrası yıllarındaki avant-garde hareketlerle özellikle Dadaizm akımı ile şekillenmiş, 1960'lı yıllara gelindiğinde müzelerin kamusal alanı yeterince temsil etmediği ve sanatın artık 'beyaz küp' olarak adlandırılan müze ve galerilerin dışına taşması gerektiği fikri yaygınlaşmıştır (Taş, 2019, s. 15). Özellikle Marcel Duchamp'ın ünlü pisuvarı, sanatın yaratımı ve özüne iliş̧kin alışllagelmiş anlamları sorunsallaştırmasının yanı sıra eserin içinde bulunduğu mekânın ve sanat kurumlarının bu anlam üzerindeki etkisinin sorgulanmasının önünü açmıştır. Böylece sanatın 'dışarısı' ile kurduğu bağıntı, dolaylı olarak sokak, kent ve toplumla bağlantı içerisine girmesi ve kamusallaşması anlamına gelmiştir. Kamusal sanat, sosyal değişimin desteklenmesinde, sanatın belirli muhalif projelere ve/veya protesto olaylarına entegre edilmesini içeren muhalefetin ayrılmaz bir parçası olarak kullanılmıștır. Yaygın toplum muhalefetin aktif bir bileșeni olarak aktivist kamusal sanat, evsizlik, AIDS, aile içi şiddet, kentsel gelişimin olumsuz çevresel etkileri gibi sosyal kaygılara ilişkin genel farkındalığı artırmayı hedeflemiştir (Hall \& Robertson, 2001, s. 17). Böylece sanatın o güne kadar kendine çizdiği sınırlar olan galeri ve müzelerin meşruiyetinin sorgulanması, kamusal alanda sanatın etkileşim, kitlelere ulaşma kolaylığı özellikleriyle birleşerek sosyal ve politik değişimi motive etmeye başlamıştır.

Farklı sanatsal temsilleri içinde bulunduran 'çok boyutlu' ve 'çok terimli' bir dışa vurum olan kamusal sanat, yalnızca kamusal desteklerle yapılabileceği gibi, özel kurum veya kişilerin bağışlarıyla ya da tamamen sanatçının kendi kaynaklarıyla üretilebilir. Kimi zaman hâkim güce karşı bir protesto, isyan, mücadele veya muhalefet amacıyla sergilenebileceği gibi aksine iktidarın gücünü göstermek amacıyla da geliștirilebilir. Sergilendiği veya yerleştirildiği mekânla bağlamsal iletişim içerisinde onu deneyimleyecek ve içselleştirecek izleyicisiyle birlikte üretilebilen kamusal sanat (Ercan, 2013, s. 222), 1960'lı yılların sanat ortamı içinde 'geçicilik' bağlamını da gündeme getirmiştir. Sanat faaliyetiyle bu faaliyetin gerçekleştirildiği mekân arasındaki ilișki, zaman kavramı ve içinde olunan 'an' ile etkileşimi, sanat ürününün ait olduğu toplum değerleri, mekânın sahip olduğu belleğin ilgili sanata dolaylı etkisinin anlamı geçiciliğin önemle üzerinde durduğu problemlerdir (Sullam, 2005). Ak'a göre ise 1980'lerden itibaren dünyada, sanatın sponsorlar aracılığıyla fonlanması, bu alanın da özelleştirilerek kamusallığının yok edilmesi anlamına gelmektedir. Sanatın ve sanatçının, iş dünyasının oluşturduğu koalisyonların atadığı küratörlere bağımlı hale gelmesi, burjuva toplumundaki kişisel özgürlük çağının da bir anlamda sonunu simgeler. 'Sanat yapma özgürlüğü', sahte kamusal biçimler içinde bir tüketim metası olarak yerini aldığı sürece var olabilmektedir. Zengin çevreler, büyük şirketler yalnızca galerilerdeki eserlere değil sokağın sesi olan sokak grafitilerine dahi müdahale etmenin yolunu bulabilmiş ve sponsorluklarla denetimli olarak yapılan bir sektöre dönüștürmeyi başarmışlardır (Ak, 2012).

1970'li yıllarda aktivizm odaklı feminist sanata, feminist sanatçı Judy Chicago kurumsal bir çerçeve sağlamıș, sanat yoluyla kitle ve eylemi ilişkilendirmiştir. Böylece popüler kültürün yarattığı kadın kimliğinin kadınlar tarafından yaratılan sanat aracılığıyla yeniden şekillendirilebileceğini düşünmüştür. Miriam Schapiro, Arlen Raven, Sheila Levrant gibi sanatçıların da katılımıyla sanatçılar kamusal alanları kullanmaya yönelmiştir. Bu noktada amaçları; aktivizmle feminizmin oldukça karmaşık ve içe içe geçen kavramlarını, büyümekte olan izleyici kitlelerine elverişli olarak ulaştırmak ve bu değişimi yeni materyallerle nasıl ifade edeceklerini belirlemek olmuştur. 70'li ylların feministlerinin iş birliği içerisinde ilişkisel yönleri vurgulayan ama aynı zamanda sonsuz değişkenlik gösteren sanatları, farklı altyapıları olan insanlar için, tarafsız bir buluşma noktasıdır. Bu doğrultuda dönemin politik ve toplumsal koşullarından da etkilenerek ırklar ve sınıflar arasında sanatsal geçişler yapmaya çalışmışlardır (Kızılkaya, 2018, s. 29). 


\section{Yöntem}

Araştırmada, Erwin Panofsky'nin ikonografik ve ikonolojik çözümleme yöntemi kullanılmıștır. Panofsky, Íkonoloji Araştırmaları isimli çalışmasında (1967) ikonografiyi "sanat eserlerinin biçimleri karşısında konuları veya anlamlarıyla ilgilenen sanat tarihinin bir kolu" olarak tanımlar. Buradan yola çıkarak eserin sahip olduğu konu veya anlam ile biçim arasındaki ayrımı ortaya koyar ve olgusal (doğal) anlam, ifadesel anlam, içsel anlamdan oluşan 3 başlık altında eleştiri yöntemini geliştirir. Doğal anlam, saf biçimsel algının sınırlarını aştı̆̆ımızda karşımıza çıkan konunun veya anlamın kolayca anlaşılan temel doğasıdır. Olgusal ve ifadesel olmak üzere ikiye ayrılır. Olgusal anlam; basitçe görünür șekillerin, fiili deneyimden tanınan bazı nesnelerle ilişkilendirilmesiyle kavranır. İfadesel anlam ise basit saptama yoluyla anlaşılabilirliğin aksine nesneler ve olaylara ilişkin gündelik aşinalığa, pratik deneyimlere sahip olmayı gerektirir. Görünür olana ait doğal ve ifadesel anlamlar, ön-ikonografik betimlemeyi oluşturur. İkincil veya uzlaşımsal anlam ise biçime karşılık konudan söz ederken yani sanatsal motiflerde beliren birincil veya doğal konunun karşısında imgeler, hikayeler ve alegorilerde beliren tema veya kavramlar dünyasını içerir (Panofsky, 2012).

Panofsky tarafından sanat yapıtının içeriği olarak açıklanan içeriksel anlam ise bir ulusun, bir dönemin, bir felsefi veya dinsel düşüncenin temel tutumunu açığa vuran ilkeler belirlenerek saptanır. Örneğin; Leonardo da Vinci'nin ünlü freskosunun bir yemek masasının etrafında toplanmıș on üç adamı gösterdiğini ve bu adamların Son Akşam Yemeği'ni temsil ettiklerini söylediğimizde kendi başına sanat eseriyle ilgilenmiş oluruz. Ancak onu, Leonardo'nun kişiliğinin, İtalyan Geç Rönesans geleneğinin ya da kendine özgü bir dinsel tutumun belgesi olarak anlamaya çalıştığımızda, sayısız başka belirtiler içinde sanat eseriyle ilgileniriz. İște bu 'sembolik' değerlerin keşfedilip yorumlanması, içeriksel anlamın temelini oluşturduğu ikonolojinin amacıdır (Panofsky, 2012, s. 30). Bu doğrultuda, seçilen eserlerin sahip olduğu görsel biçim, üretildiği toplumsal koşullar ve feminist eleştiri ile ilişkisi bağlamında yorumlanmıştır.

Çalışmada; eşit önem atfettikleri aktivizm, feminizm ve sanat üçgeninin kesişiminde yer almaları, 1970'lerden itibaren geliştirilen feminist çalışmaların ana kavramlarını çalışmalarında kullanarak feminist söylemin sanatta temsilinde öncü bir rol oynamaları nedeniyle Guerrilla Girls sanatçı grubu örneklem olarak seçilmiştir. İkinci dalga feminizmle, dönemin siyasi atmosferine karşı gelişmekte olan aktivist reaksiyon bir araya geldiğinde 1980 'li yıllar, Guerrilla Girls için gözlemleme ve gelişmenin sonrasındaki ifade ediş sürecine denk gelmektedir. Guerrilla Girls'ün tüm eserlerindeki ortak tema sanat alanındaki cinsiyet eşitsizliğinin feminist eleștirisidir. Buna karşın bazı çalışmalarının ırkçılığa yönelik eleştiriyi de içermesi nedeniyle bunlar örneklemin dıșında bırakılarak temsil yeterliliği olduğu düşünülen 5 örnek, Panofsky'nin ikonografik ve ikonolojik çözümleme yöntemiyle analiz edilmek üzere çalışmaya dahil edilmiştir.

\section{Feminist Aktivist Sanat: Guerrilla Girls}

Çalışma (bkz. Şekil 2), New York'taki Public Art Fund kuruluşunun Guerrilla Girls sanatçı grubundan bir ilan panosu tasarlamasını istemesiyle ortaya çıkmıştır. Metropolitan Sanat Müzesi'nde 1989'da sergilenen kadın sanatçıların ve sanat eserlerindeki çıplak kadın bedenlerinin sayısının ironik karşılaștırmasını konu almaktadır. Eserin yeterince 'açı olmadığı' gerekçesiyle Kamu Sanat Fonu tarafından reddedilmesi sonucu Guerrilla Girls, New York otobüslerinde bir reklam alanı kiralamış, bu kez 'görüntünün çok müstehcen olduğu' gerekçesiyle iptal edene kadar posteri burada sergilemiştir (Guerrilla Girls, 1989a). 1985 yllında bir araya gelen Guerrilla Girls üyeleri, sanat kurumlarını ziyaret ederek sanat eserlerinin erkek-kadın konu oranlarını belirlemek amacıyla sıklıkla sayımlar gerçekleștirmektedir. Henüz ilk yıllarında tasarladıkları Kadınların Metropolitan Müzesine Girebilmeleri İçin Çıplak mı Olmaları Gerekir? isimli bu ilk renkli posterleri, grubun en ikonik imajı olmuştur.

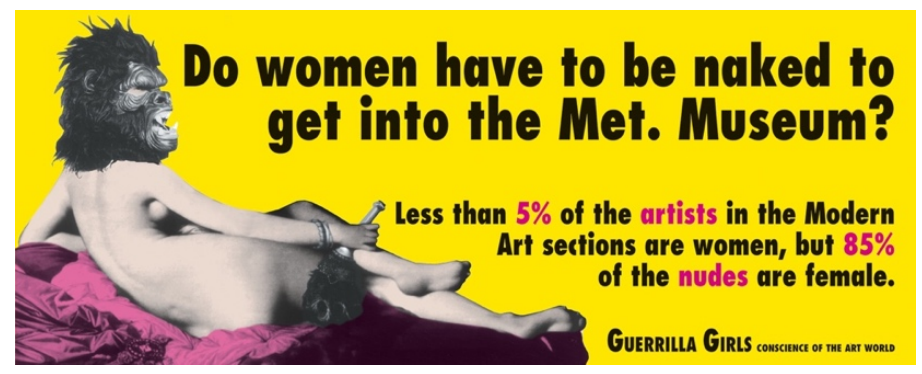

Şekil 2. Do Women Have To Be Naked To Get Into the Met. Museum?, Guerrilla Girls, 1989a. 
Görselin ilk olarak düz anlamına baktığımızda goril maskesi takan çıplak bir kadın figürüyle karşılaşırız. Yöneltilen soru, görselin büyük kısmını kaplayarak sarı zemin üzerinde dikkat çekmektedir. Metnin tamamını 'bold' karakterler oluștururken üstte yer alan ifade daha büyük puntolarla yazılmıștır. Yanı sıra metinde yer alan bazı kelimeler kırmızı renkle vurgulanmıştır. Uzlaşımsal anlama baktığımızda ise kullanılan kadın figürünün Jean Auguste-Dominique Ingres'in La Grande Odalisque 1814 adlı ünlü resmine (bkz. Șekil 3) dayandığını görmek mümkündür. Çerçevenin neredeyse tamamını kaplayarak paralel șekilde konumlandırılmış bu çalışmada yatağın üzerine uzanmış çıplak kadın figürü yüzünü resme bakan bizlere dönmüştür. Eserin orijinalinde, anatomik gerçekçilikten uzak vücut biçimi ve duruş açısıyla bir cariye olarak resmedilen kadın, idealize edilmiş görünümüyle ve çıplaklığıyla şehveti vurgulamaktadır. Ingres'in resminden yararlanarak tasarlanan posterde ise bedenin birebir kopyalandığı ancak figürün başının yerini goril maskeli bir kadının aldığı görülmektedir. Böylece kadın bedeninin salt cinsel anlam içeren bir objeye indirgendiği eleştirisinin Panofsky'nin işaret ettiği içeriksel anlamı oluşturduğu görülmektedir. Müzelerde yer alan eserlerin sanatçlarının \%5'inden azı kadınken çıplakların ise \%85'inin kadın olduğu bilgisi üzerinden, sanatın içerisinde kadının ancak çıplaklığı ve nesne konumuyla yer alabildiği, alaycı ve eleştirel bir üslupla sunulmuştur.

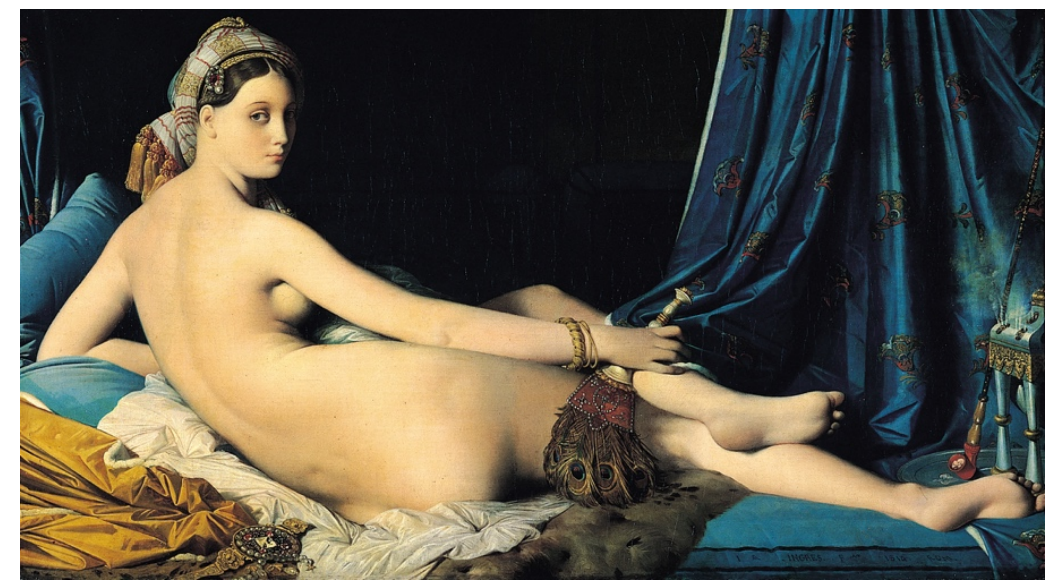

Şekil 3. La Grande Odalisque, Jean Dominique Ingres, 1814.

Dearest Art Collector, çoğunlukla siyah beyaz afiş, çlkartma ve posterler bulunan Guerrilla Girls portföyünde daha renkli ve bu nedenle alışılmadık bir örnek oluşturmaktadır. Guerrilla Girls, bu posteri Amerika Birleşik Devletleri'ndeki tanınmış sanat koleksiyoncularına göndererek, sahip oldukları eserlerin içerisinde kadın sanatçllara ait olanlarının ne kadar az olduğuna işaret etmiştir. Başka dillere çevrilmesiyle ABD dıșındaki koleksiyonculara da gönderilmiştir (The Art Story, t.y.). Postere ilk bakıșta doğal anlamı, bir mektubu andıran sayfada pembe zemin üzerine yazılmış el yazısı oluşturmaktadır. Metnin öncesinde sayfanın başına yerleştirilmiş papatya çiziminde üzgün bir ifade göze çarpmaktadır. Metnin içeriğinde ise hitap edilen isimsiz sanat koleksiyoncusuna ait koleksiyonun yeterince kadın eseri içermediği belirtilmekte ve bu durumun kendileri tarafından da üzücü bulunduğunun bilindiği ifade edilmektedir. Gerçekleri yansıtmadı̆̆ı anlaşılsa da kullanılan kibar üslup ve metni yazan kişinin bir kadın olduğuna ilişkin renk, yazım dili, yazı stili gibi göstergeler (bkz. Şekil 4) uzlaşımsal anlamı meydana getirmektedir. Kullanılan kıvrımlı, zarif, yumuşak el yazısıyla (Garfield, 2020) metnin bir mektup olduğunun anlaşılması istenmiştir.

Tüm bu görsel düzenlemelerin bilgisi, kullanılan metin, font, figürlerin tasviri sonucunda oluşan içeriksel anlam; sanat dünyasında kadınlara tanınan alanın sınırlılığına alaycı bir eleştiri yapma amacı taşımaktadır. Kullanılan el yazısı ve üzgün yüzlü çiçekle eril bakışın kadınlara atfettiği feminenliğin bir ifadesi oluşturulmaya çalıșılmıştır. Bir karşıtlık ilişkisi içerisinde konumlandırılmış kadın ve erkekliğe ilişkin toplumsal rollerde kadın edilgen ve seyredilen bir birey olarak eril özelliklerin beklentilerine uygun davranış kalıplarıyla hareket etme zorunluluğundadır. Her ne kadar metnin içeriği bir sorunu dile getiriyor olsa da kullanılan üslubun kibarlığı ile bu toplumsal cinsiyet rollerinin gerekliliğini yerine getirmek amacıyla kadının, yalnızca tek bir cinsiyete özgü bir olguymuşçasına her şartta 'kibar' davranmasının beklenmesi eleştirilmiştir. Kadının şikâyette veya bir talepte bulunurken dahi bunu kabul edilebilir bir yolla yapmasının beklenmesi ve kadının bir sanatçı olarak erkeklerin gözünde var olabilmesinin biraz da bu beklentiyi karşılamasına bağlı olması yerilmiştir. 


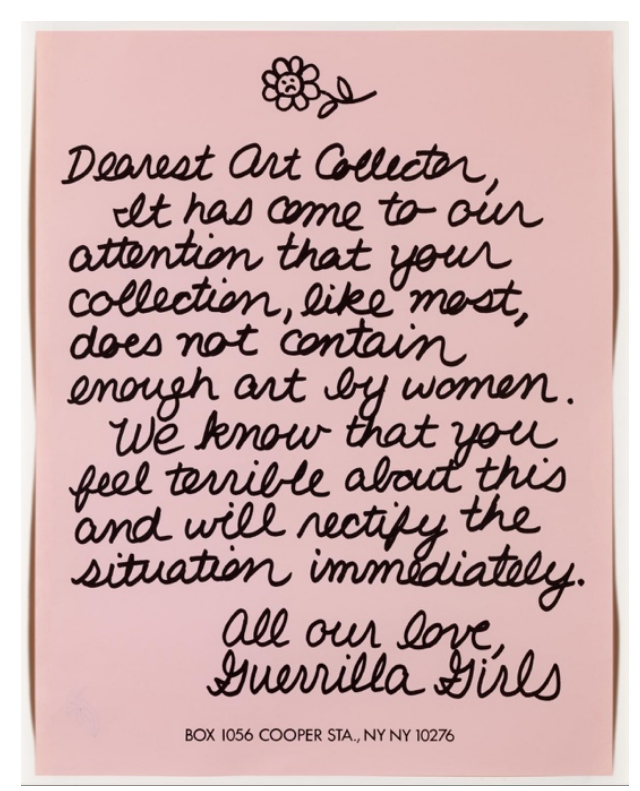

Şekil 4. Dearest Art Collector, Guerrilla Girls, 1986.

Guerrilla Girls Talk Back: The First Five Years, A Retrospective: 1985-1990 portföyünde yer alan 30 afișten biri olan çalışma (bkz. Şekil 5) 1991 yılında East Fine Arts Gallery'nin gezici sergisinde, 1994 yılında aynı galerinin bu kez Texas Women's University'deki sergisinde ve 2011 yllında National Museum of Women in the Arts'ta sergilenmiștir (Guerrilla Girls, t.y.-c). Yanı sıra bir Guerrilla Girls takipçisinin 1000 dolarlık bağıșıyla bu afiș, ABD’nin en iyi sanat dergilerinden biri olan Artforum'da reklam olarak yayınlanmıștır (Guerrilla Girls, 1989b). Bu portföy içerisinde yer alan çoğu afiș ve posterde olduğu gibi görselin tamamına siyah beyaz renk kullanımı hakimdir. Büyük ve kalın puntoyla yazılmış başlığın altında 13 maddeden oluşan bir metin listesi yer almaktadır. Kolayca anlaşılan temel doğasını içeren doğal anlamı ile çalışma; kadın sanatçı olmanın avantajlarının sıralandığı bir listedir. Ancak uzlaşımsal anlamı oluşturan içeriğe baktığımızda kadın sanatçılar için olumsuz durum ve unsurların Guerrilla Girls için vazgeçilmez bir unsur olan mizahın kullanımıyla sıralandığı görülmektedir.

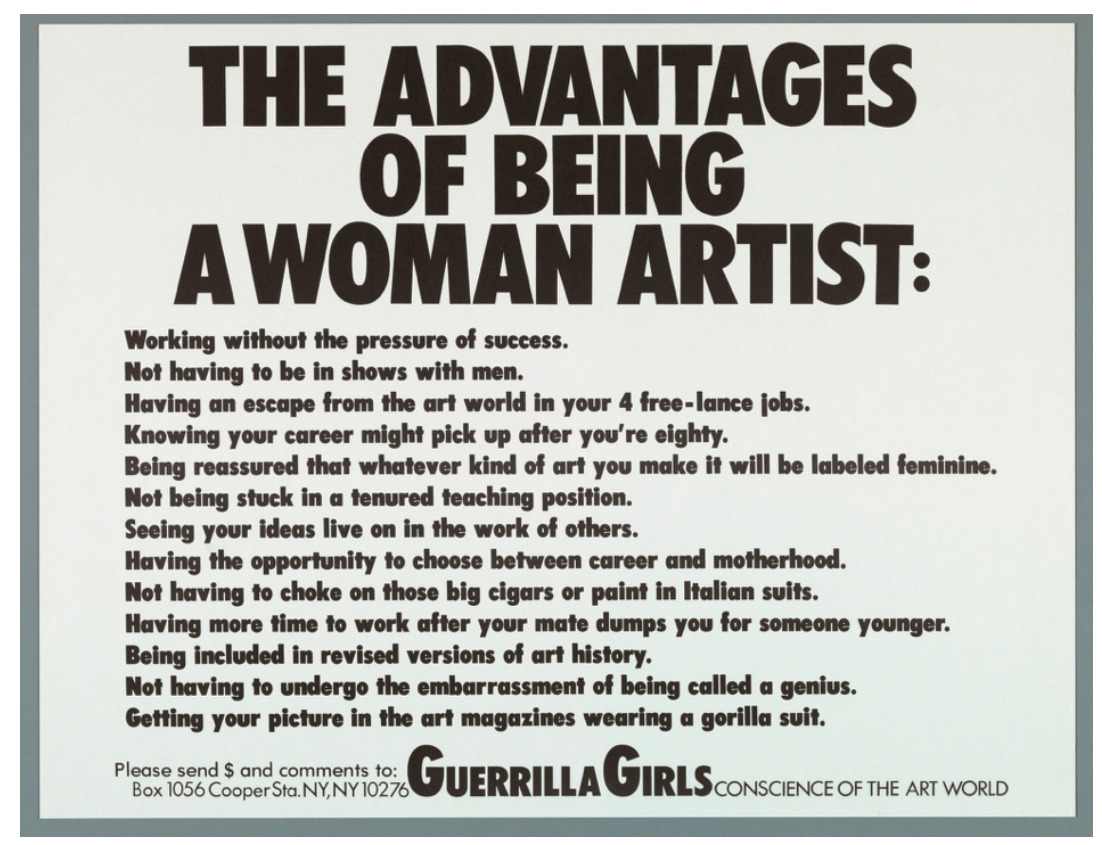

Şekil 5. The Advantages of Being a Woman Artist, Guerrilla Girls, 1988.

İlk madde olan "başarının baskısı olmadan çalışmak", diğer tüm maddelerin ortak temelini oluşturan, kadın sanatçıları dışarıda bırakan sanat piyasasına yönelik eleştiridir. Toplumsal yaşamda tanımlanan örüntüler 
doğrultusunda özne olması engellenerek seyirlik bir nesneye indirgenen kadın, iş ve kariyer alanlarında yaratıcılık ve yetenek sahibi olduğu varsayılan erkeğin gerisinde bırakılmıștır. Sanat piyasası özelinde ise topluluk, çoğu zaman yaratıcılığı içeren özgün ve albenili bu dünyanın kendine özgü özelliklerini kullanarak adeta ifşa eden bir tavır takınmıştır. Örneğin; piyasa içerisinde yaygın hale getirilen güvencesiz çalışma ve çalışma yaşamını yalnızca sanata dair olduğu için 'ücret gerektirmeyen, gönüllülük esasına dayalı bir uğraş' olarak gören piyasa aktörlerini, birden çok freelance iște birden çalıșmak zorunda bırakılmak üzerinden eleștirmișlerdir. Bourdieu bunu, sanatçının romantik betimlemesinin yansıttığı ekonomik çıkardan arınmıș anlayış olarak niteleyerek sanat piyasasının ekonomiye dayanma zorunluluğuna dikkat çekmiştir (Bourdieu, 1999, s. 238). Sanat dünyası içerisinde yer alamayan kadının erkeğin egemenliği altındaki bu 'şovun' bir parçası olamadığına değinilirken seçilen ifadelerle bir ironi de yaratılmak istenmiş, böylece eleştirel ve ciddi mesajlarını erişilebilir ve ilgi çekici hale getirerek sunmuşlardır. "Kariyerinin seksen yaşından sonra gelişebileceğini bilmek" ifadesinde Barbara Hepworth, Lee Krasner, Louise Nevelson ve sanat tarihine katkıları ancak kariyerlerinin en sonunda kabul edilen sayısız diğer kadın sanatçıya gönderme yapılmaktadır.

"Ne tür bir sanat yaparsan yap kadınsı olarak etiketleneceğinden emin olmak" ifadesinde ise sanatın erkek egemen kurumsallığıyla mücadeleleri sonucunda bir yer edinebilme imkânı bulamamıș, kabul görmemiș ve hatta salt sanatsal üretimleri nedeniyle türlü zorbalıklara maruz kalmış kadın sanatçıları bulmak mümkündür. Kadın kimliğiyle ne toplumsal yaşamda ne de sanat dünyasında yer bulamadıklarından kimi zaman yalnızca üretimde bulunabilme ve bunu paylaşabilme özgürlüğüne erişebilmek için kimi zamansa buna mecbur bırakıldıkları için eserleri babaları veya kocaları tarafından imzalanmış (Ulusoy, 1999, s. 54), 'sanat tarihinin revize edilmiş versiyonlarına dahil olmak' üzere özgün kimliklerini bir kenara bırakmışlardır. Marietta Robusti, Artemisia Gentileschi, Judith Lester, Camille Claudel gibi birçok sanatçının yaşam öyküsüne bakıldığında sahip oldukları yetenekleri ve sanatsal üretimde bulunma istekleri dolayısıyla baskıyla karşılașıp yabancılaștırıldıkları ve aşağılandıkları, tüm başarılarının bașkaları tarafından sahiplenildiği görülmektedir. Guerrilla Girls'ün de ironik bir betimlemeyle aktardığı gibi kadınlar ancak fikirlerinin başkalarının çalışmalarında yaşadığını görme 'şansına' erişebilmiştir. Kariyer ve annelik arasında seçim yapma fırsatı maddesiyle, toplumsal cinsiyet hiyerarşisinde kadını ev içi alana hapseden ve var oluşunu annelikle sınırlandıran cinsiyetçi sosyo-kültürel yapının eleştirisini yapmışlardır. Sanat dergilerinde goril kıyafeti içerisinde göründükleri fotoğraflarla yer aldıklarını belirttikleri son madde ise yalnızca sanatçı kimlikleriyle ve çalışmalarıyla yer aldıkları bir kariyer yerine öncelikli olarak kadının sanat dünyasındaki haksız konumuyla mücadele etmek zorunda kalan grubun öznel deneyimini ele almıştır.

Sarı zemin üzerinde siyah ve kırmızı renkte yazılmış metnin yer aldığı bu billboard çalışmasında resmin sağına yerleştirilmiş kadın figürü göze çarpmaktadır (bkz. Şekil 6). Çalışmanın düz anlamını oluşturan bakışlarını izleyiciye yöneltmiş kadın figürünün, ağzının yeşil bir yaprakla kapalı olduğu görülmektedir. Çalışmanın uzlaşımsal anlamını oluşturan ise kadın figürünün ünlü Mona Lisa tablosundan alınmış olması, sarı zemin üzerindeki kırmızı sözcüklerle 'kadınların seçme hakkı' ve 'sanatın sansürlenmesi'ne dikkat çekilmesidir. Sanat tarihinin simge eserlerinden biri olan Mona Lisa'nın ağzının kapatılmış olması, kadınların sanat dünyasında eserleriyle var olabilmesi ve kendini ifade edebilme özgürlüğünün engellenmesine yapılan vurgudur. Bu vurguyu güçlendirecek şekilde diğer işlerine hâkim olan siyah-beyaz tonların ve metnin içeriğine yaslanan sade grafiklerin aksine sarı ve parlak renkte bir fon kullanmış, kelimelerin renk kullanımında kırmızıyı seçerek zıtlık ve dikkat çekicilik yaratmışlardır.

Tüm bunların sonucunda oluşan içeriksel anlama baktığımızda panodaki görsel kompozisyonun sanatla olan ilişkisinin Mona Lisa ile kurulduğunu, kadın haklarına ve kadın sanatçılara ilişkin sansürün tema olduğu çalışmada anlama ilişkin vurgunun renklerin psikolojik etkilerinden yararlanılarak yapıldığını söylemek mümkündür. Daha da önemlisi kullanılan Mona Lisa figürünün ağzını kapatanın bir incir yaprağı olması, Havva'ya atıftır. Tevrat'ın Dünyanın Yaratılışı bölümünde Havva'nın yasak meyveyi koparıp yedikten sonra yanındaki kocasına verdiği, böylece ikisinin de gözleri açıldığı anlatılmıştır. Çıplak olduklarını anlayan Âdem ve Havva, bu yüzden incir yaprakları dikip kendilerine önlük yaparlar. Âdem ve Havva'nın Tanrı'ya itaatsizlik ettikten sonra duydukları utancı ve suçluluğu örtmeye, ortadan kaldırmaya çalışarak bedenlerini örttükleri incir yaprağı, 'görülmemesi gereken yerlerini' örtmek amacıyla bu kez kadını susturmak için kullanılmıștır. ${ }^{1}$ Guerrilla Girls'ün Public Art Fund'ın PSA: Public Service Art sergi serisinin dördüncü ve son sanat eseri olarak West Side Highway üzerinde yer alacak bir reklam panosu

\footnotetext{
${ }^{1}$ Tevrat'ın ilk kitabı Tekvîn evrenin ve insanın yaratılışını, 3. Bölümü ise Âdem ve Havva'nın öyküsünü içerir.
} 
şeklinde tasarlanan bu iş, ironik şekilde ilk başvuruda Kamu Sanat Fonu tarafından sansürlenmiștir (Guerrilla Girls, t.y.-b).

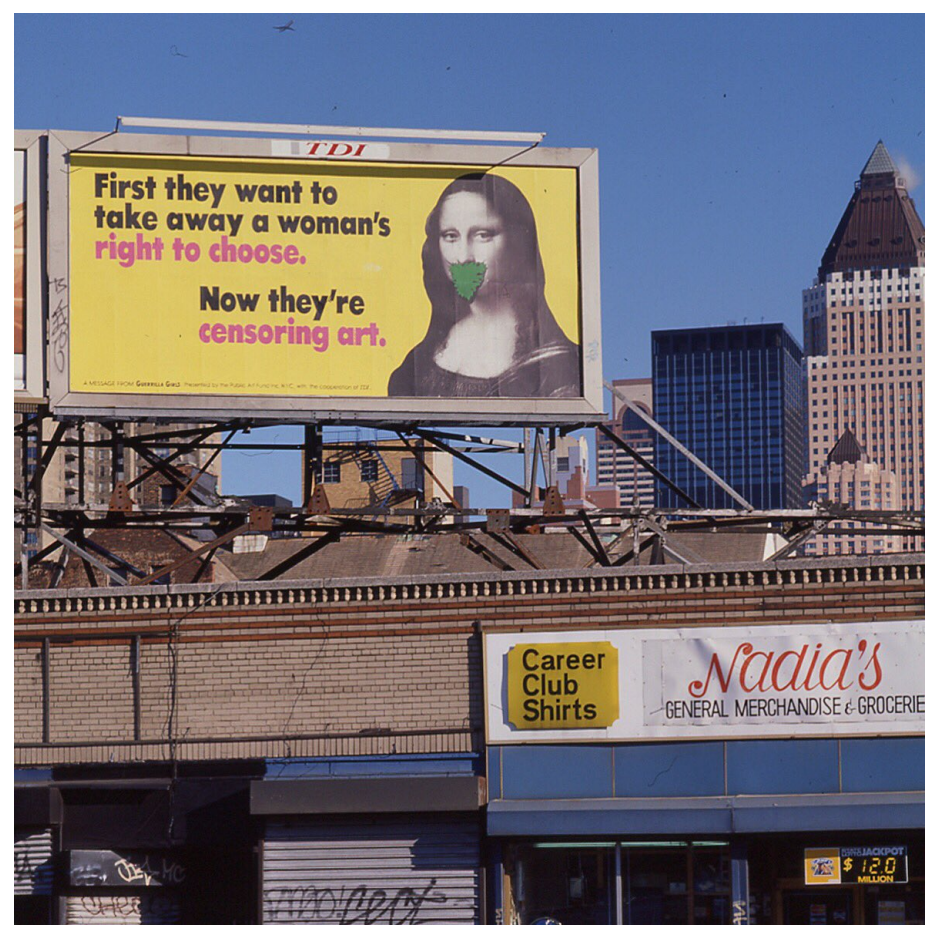

Şekil 6. First They Want To Take Away A Woman's Right To Choose... Now They're Censoring Art, Guerrilla Girls, 1991.

Pembe zemin üzerinde yine pembe Türk kahvesi fincanının yer aldığı posterde, sarı oklarla gösterilmiş şekiller görülmektedir ve başlık, kompozisyonun geneline uygun olacak şekilde beyaz ve kırmızı renkte yazılmıștır (bkz. Şekil 7). Așağıda yer alan, siyah ve sarı olmak üzere farklı fontlarda yazılmış metinler ise bize 'falı' açıklamaktadır. Yanı sıra fincan içerisine yerleștirilmiş uzanan kadın figürü, gülen bir yüz, denizcilikte kullanılan çapa ve para birimi şekilleri düz anlamı oluşturan diğer unsurlardır. Çalışmanın uzlaşımsal anlamını sorguladığımızda, kullanılan metinlerin içeriğinden İstanbul'daki galeri ve müzeleri, kadın sanatçların durumu üzerinden inceleyen ve bunu kahve falıyla görselleștiren bir çalışmayla karşı karşıya olduğumuzu anlarız. Pembe rengin ağırlıkla kullanılması tıpkı Dearest Art Collector'da olduğu gibi eleştirel bir feminenliğin çağrışımını yaratmaktadır. Diğer Guerrilla Girls çalışmalarında olduğu gibi çalışmaya adını da veren başlık, içeriği ve yaratılmak istenen anlamı açıklamaya yardımcı bir unsurdur ve 'malum olma' ifadesi kahve falı ile ilişkilendirildiğinde anlamını kazanmaktadır.

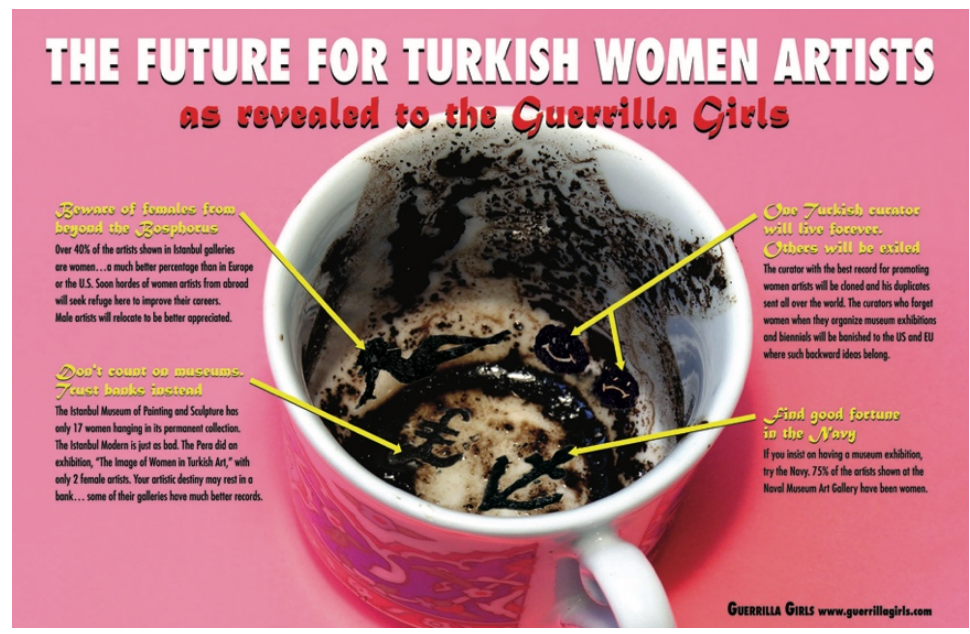

Şekil 7. The Future for Turkish Women Artists as Revealed to the Guerrilla Girls, Guerrilla Girls, 2006. 
“Boğaz’ın ötesindeki kadınlara dikkat edin” ifadesi (bkz. Şekil 7), Türkiye'deki kadın sanatçlların Avrupa ve ABD'deki hemcinslerinden daha iyi durumda bulunduğunu, İstanbul'daki galerilerde sergilenen çalışmaların yüzde 40'ının kadınlara ait olduğunu ifade etmektedir. "Müzelere güvenmeyin, onun yerine bankalara güvenin" ifadesiyle İstanbul Resim ve Heykel Müzesi'nin kalıcı koleksiyonunda 17 kadın sanatçının, Pera Müzesindeki Türk Resminde Kadın Imgesi sergisinde ise yalnızca 2 kadın sanatçının eserinin yer aldığına dikkat çekilmiștir. Küreselleșmeyle birlikte, kültürün özelleștirilmesi ve finansın ekonomide egemen olması sonucu, sanat da önemli bir finans aracına dönüşmüştür. Finans dünyasını yöneten spekülasyon giderek sanatı da teslim almasıyla müzayede, sanatın değerlendirildiği bütün diğer ortamların önüne geçmiş; müze, fuar, bienal ve galerilerin işleyişi üzerinde, hatta sanat tarihi ve eleştiri yazınında bir hegemonya oluşturmuştur. 1990'larda tırmanan bu gelişmeyi çağdaş sanatın yoğun olarak piyasalaştırılması izlemiş, sanat bir lüks, sanatçı da bir girişimci olmaya yönlendirilmiștir (Thompson, 2012). Böylece ekonomide söz sahibi, finans sektörünün kalbi bankalar, sanat-kültür faaliyetleriyle bilinirliklerini artırıp imajlarını güçlendirmektedirler. Türkiye'de, destekledikleri sanat organizasyonları, kurdukları yayınevleri, merkezler ve galeriler bünyesinde sürdürdükleri aktivitelerle kültür-sanat camiasının belki de en önemli destekleyicisi konumundadırlar (Xsights, 2017). Bu doğrultuda müzelerde kendine yer bulamayan kadın sanatçlların sanatsal kaderinin sponsorluk faaliyetleri kapsamında sanat kurumlarına sahip bankaların ellerinde olduğu uyarısı yapılmıştır.

"Bir Türk küratör sonsuza dek yaşayacak" ifadesinde mizahi bir dille sergi ve bienal düzenlerken kadınları unutan küratörlerin bu tür geri kafalı düşüncelerin ait olduğu yerlere gönderileceği belirtilirken "șansınızı donanmada deneyin" ifadesiyle ise Deniz Müzesi Sanat Galerisi'nde sergilenen yapıtların \%75'inin kadın sanatçllara ait olması dikkat çekici ve ilginç bir bilgi olarak sunulmuştur. Guerrilla Girls, 2005'te İstanbul Modern'in direktörü Rosa Martinez tarafından 'Venedik-İstanbul' sergisi kapsamında Türk kadın sanatçlarının durumunu inceleyen bir proje hazırlamaya davet edilmiştir. İlk kez bir kurumun, içerisinde yer aldığı sanat dünyasını eleştiren bir çalışma için davette bulunduğunu belirten topluluk, bunun ABD'de olamayacağını düşündüklerini belirtmiştir. Avrupa sisteminin içinde yer alan Bienal'in, kurumları iyileştirmenin bir yolu olarak onları içeriden eleştirmeye verdiği değerin önemini vurgulamışlardır (Hamsici'den aktaran Vargl, 2009). Amerika ve Avrupa'nın sanat kurumları ve piyasalarının kurumsallığ bağlamındaki karşılaştırmalarında Türk kadın sanatçllar; Doğu’yu çağrıștıran yazı stilleri, kahve falı gibi Türk kültürüyle özdeşleșmiş unsurların kullanılması sonucu oryantalist bir bakışla yer almıştır. Böylece içeriksel anlam, tıpkı kahve falındaki şekillerin yorumlanmasıyla sezgisel kehanetlere ulaşma amacında olduğu gibi Türk kadın sanatçlların sanat piyasasındaki konumlarına ilişkin bilgilerin, Türk ve Doğu kültüründen öğeler ile simgeselleştirilmesi sonucu oluşmuştur.

\section{Sonuç}

Guerrilla Girls, sanat tarihine ve günün koşullarında sanatın işleyiş pratiklerine yönelik feminist bir eleştiriyi getirirken bunu salt kadın bedeninin seyir unsuru olarak teşhir edilmesi özelinde değil aynı zamanda yaratılan doğuştan yetenekli erkek sanatçı imajının gerçekdışılığını ortaya koyarak 'sanatçı olarak kadın'ı vurgulaması bağlamında da yapmıştır. 1960 ve 1970’li yıllarda süren politik çalkantılar, farklı sosyal kimliklerin ayrımcılığa karşı ortak mücadelesini kapsayan kesişimsel bir feminizme inanmalarında ve üretimlerinin/eylemlerinin politize bir karaktere bürünmesinde etkili olmuştur. Tasarım teknikleri ve reklamcılık taktiklerini kullanmaları dolayısıyla kolayca sanat eseri kategorisinde değerlendirilemeyen işleri; eylemi ve işlevselliği temel alan aktivist karakterleriyle birlikte değerlendirildiğinde anlam kazanmaktadır. Sanat piyasasının hiyerarşisinden ve erkek egemen sanat kurumlarının kabulüne tabi olma zorunluluğundan kurtulabilmek için yöneldikleri kamusal alan, reklam ve propaganda temelli sanat pratiklerine yön vermiştir. Ancak ironik şekilde ilerleyen yıllarda bu çabalarının sonucunda fark edildikleri kurumlar tarafından işleri sergilenmiş ve içeriden müdahale veya eleştiri olanağı da bulmuşlardır. Böylece kamusal alanın gücünü kullanarak sanat ve aktivizm arasında kesişim yaratan protest eylem biçimleri; günün koşullarında yüzlerce isimsiz sanatçının katılımıyla devamlı bir dönüşüm içerisinde gelişmiştir. Apolitik bir sanat fikri karşısında yer alarak sanat tarihine yönelik feminist eleştiriyi merkeze alan çalışmalarında kişisel ilişkilerden doğan iltimasçılık ve küresel sermayenin sanat piyasasındaki rolü gibi konulara da yer vermişlerdir.

Örnekleri incelenen üretimlerine hâkim olan en önemli unsurlardan biri mizahtır. Bu mizahi söylem ve ifade biçimleri, değişime yönelik talebi barındırmaktadır. Kadının çıplak bedeni olmadan yer alma şansına erişebileceği sanat kurumları, erkeğe özgü sanılan sanatsal yaratımı ortaya koyabilmesi için kadın sanatçıların özgürleștirilmesi ve görünürlüğünün sağlanması taleplerini kendilerine özgü gerilla 
taktikleriyle hayata geçirmiş; sanatı, bugün biraz daha güçlü konumdaki kadın sanatçıları var eden koşullar için mücadele aracı olarak kullanmışlardır.

\section{Kaynakça}

Ak, B. (2012). Kamusal alan ve sanat. Mimarlık Dergisi, 364 [Mart-Nisan]. Erişim adresi: http://www.mimarlikdergisi.com/index.cfm?sayfa=mimarlik\&DergiSayi=378\&RecID=2902

Antmen, A. (Ed.). (2014). Sanat/Cinsiyet: Sanat tarihi ve feminist eleștiri. İstanbul: İletişim Yayınları.

Arruzza, C., Bhattacharya, T. ve Fraser, N. (2019). \%99 için feminizm: Bir manifesto (U. Özmakas, Çev.). İstanbul: Sel Yayıncılık.

Bourdieu, P. (1999). Sanatın kuralları (N. K. Sevil, Çev.). İstanbul: Yapı Kredi Yayınları.

Davidoff, L. (2002). Feminist tarihyazımında sınıf ve cinsiyet (Z. Ateşer, S. Somuncuoğlu, Çev.). İstanbul: İletişim Yayınları.

Donovan, J. (2014). Feminist teori: Entelektüel gelenekler (A. Bora, M. A. Gevrek, F. Sayılan, Çev.) [8. Baskı]. İstanbul: İletișim Yayınları.

Ercan, M. A. (2013). Kamusal sanatın 'kamusallığı': Erişim, aktör, fayda yaklaşımı. Idealkent, 10(4), 220-255.

Fraser, N. (2009). Feminizm, kapitalizm ve tarihin oyunu (G. Kurtsoy, Çev.). Kültür ve Siyasette Feminist Yaklașımlar, 9. Erișim adresi:

http://www.feministyaklasimlar.org/sayi-09-ekim-2009/feminizm-kapitalizm-ve-tarihin-oyunu/

Garfield, S. (2020). Tam benim tipim: Bir font kitabı [8. Baskı]. İstanbul: Domingo Yayınları.

Guerrilla Girls. (t.y.-a). Guerrilla Girls: Reinventing the 'f' word: feminism. Erişim adresi: https://www.guerrillagirls.com/about

Guerrilla Girls. (t.y.-b). 1991 projects. Erişim adresi: https://www.guerrillagirls.com/1991-projects/1991guerrillagirls-ivebegged

Guerrilla Girls. (t.y.-c). The Guerrilla Girls' complete chronology. Erişim adresi: https://www.guerrillagirls.com/chronology-exhibitions

Guerrilla Girls. (1986). Dearest art collector [Poster]. Tate Modern, London.

Guerrilla Girls. (1988). The advantages of being a woman artist [Poster]. Tate Modern, Londra.

Guerrilla Girls. (1989a). Do women have to be naked to get into the met. Museum? [Poster]. Tate Modern, Londra. Erișim adresi: https://www.guerrillagirls.com/naked-through-the-ages

Guerrilla Girls. (1989b). The advantages of being a woman artist [Poster]. Art Metropole, Toronto. Erişim adresi:

https://artmetropole.com/shop/585

Guerrilla Girls. (1991). First they want to take away a woman's right to choose... Now they're censoring art [Açıkhava tasarımı]. Public Art Fund, New York. Erişim adresi:

https://www.publicartfund.org/exhibitions/view/first-they-want-to-take-away-a-womans-rightto-choose-now-theyre-censoring-art/

Guerrilla Girls. (2006). The future for Turkish women artists as revealed to the Guerrilla Girls [Poster]. Whitney Amerikan Sanatı Müzesi, New York.

Guerrilla Girls_Artist. (t.y.). PosterMostra. Erișim adresi: https://www.postermostra.com/en/portfolio_page/guerrilla-girls/

Habermas, J. (1995). Kamusal alan: Ansiklopedik bir makale. Birikim Dergisi, 70, 62-66. Erișim adresi: https://birikimdergisi.com/dergiler/birikim/1/sayi-70-subat-1995/2269/kamusal-alanansiklopedik-bir-makale/4966

Hall, T. \& Robertson, I. (2001). Public art and urban regeneration: Advocacy, claims and critical debates. Landscape Research, 26(1), 5-26. 
Hooks, B. (2012). Feminizm herkes içindir (E. Aydın, B. Kurt, Ş. Özgün ve A. Yıldırım, Çev.). İstanbul: BGST Yayınları.

Ingres, J. D. (1814). La Grande Odalisque [Tuval üzerine yağlı boya]. Louvre Müzesi, Paris.

Karakaşoğlu, Y. (2017). Türkiye'deki kadın hareketlerinin farklı şehirlerde karşılaştırılması araștırma projesi raporu. Universität Bremen. Erișim adresi: https://www.uni-bremen.de/fileadmin/user_upload/fachbereiche/fb12/fb12/pdf/A-

IB/Forschungsergebnisse/I.Karakasoglu_TR.pdf

Kızlkaya, E. (2018). Sanatta yeni toplumsal stratejiler ve pratikler: Yeni tip kamusal sanat (Yüksek lisans tezi) Ișık Üniversitesi Sosyal Bilimler Enstitüsü, İstanbul. Erișim adresi: https://acikerisim.isikun.edu.tr/xmlui/handle/11729/1327?locale-attribute=en

Mulvey, L. (1997) Görsel haz ve anlatı sineması (N. Abisel, Çev.). 25. Kare, 21, 38-46.

Nochlin, L. (1971/2014). Neden hiç büyük kadın sanatçı yok? Antmen, A. (Ed.), Sanat/Cinsiyet: Sanat Tarihi ve Feminist Eleștiri (s. 119-156) içinde. İstanbul: İletişim Yayınları.

Ögüt, H. (2009). Kadın filmleri ve feminist karşı sinema. Cogito: Feminizm, 58[Bahar], 202-218.

Öztürk, Ş. (Ed.). (2009). Feminizm. Cogito Dergisi, 58[Bahar], 5-11.

Panofsky, E. (2012). İkonografi ve ikonoloji: Rönesans sanatının incelenmesine giriş (0. Düz, Çev.), İstanbul: Pinhan Yayınları.

Peterson, T. G. ve Mathews, P. (2014). Sanat tarihinin feminist eleştirisi. Antmen, A. (Ed.), Sanat/Cinsiyet: Sanat Tarihi ve Feminist Eleştiri (s. 13-75) içinde. İstanbul: İletişim Yayınları.

Rochefort, F. (2020). Feminizmler tarihi (Ö. Altun, Çev.). İstanbul: Sel Yayıncllık.

Salomon, N. (2014). Sanat-tarihi kanonu: Dışlama günahları. Antmen, A. (Ed.), Sanat/Cinsiyet: Sanat Tarihi ve Feminist Eleştiri (s.161-187) içinde. İletişim Yayınları, İstanbul.

Saygılıgil, F. ve Berber, N. (Ed.). (2020). Modern Türkiye’de siyasî düşünce Cilt 10 Feminizm. İstanbul: İletişim Yayınları.

Sullam, B. (2005). 1960 sonrası kamusal alanda sanat ve geçicilik (Sanatta yeterlik tezi). Marmara Üniversitesi Güzel Sanatlar Enstitüsü, İstanbul. Erişim adresi:

https://www.e-skop.com/skopbulten/tezler-1960-sonrasi-kamusal-alanda-sanat-ve$\%$ E2\%80\%9Cgecicilik\%E2\%80\%9D/2343

Taş, İ. (2019). Kamusal sanat aktivizmi: Stüdyo 21 Lefkoşa (Yüksek lisans tezi). İstanbul Teknik Üniversitesi Fen Bilimleri Enstitüsü, İstanbul. Erişim adresi: https://tezarsivi.com/kamusal-sanat-aktivizmi-studyo-21-lefkosa

Tate Kids. (t.y.). Who are the Guerrilla Girls? Erișim adresi: https://www.tate.org.uk/kids/explore/who-is/who-are-guerrilla-girls

The Art Story. (t.y.). The Guerrilla Girls Artworks. Erişim adresi: https://www.theartstory.org/artist/guerrilla-girls/artworks/

Thompson, D. (2012). Sanat mezat: 12 milyon dolarlık köpekbalığı çağdaș sanatın ve müzayede evlerinin tuhaf ekonomisi (R. Akman, Çev.). İstanbul: İletişim Yayınevi.

Xsights. (2019). Türkiye'nin kültür sanat bankaları. Erişim adresi: https://www.xsights.co.uk/tr/turkiyenin-kultur-sanat-bankalari-9197/

Ulusoy, D. (1999). Plastik sanatlarda toplumsal cinsiyet. Hacettepe Üniversitesi Edebiyat Fakültesi Dergisi, 16(2), 47-73.

Vargı, E. (2009). Guerilla Girls- Gerilla Kızlar. Fotografya, 22. Erişim adresi: http://www.fotografya.gen.tr/TR,1818/guerilla-girls---gerilla-kizlar.html 